\title{
O NOWEJ KREACJI ZABYTKÓW, CZYLI W POSZUKIWANIU WYIDEALIZOWANEJ WIZJI PRZESZŁOŚCI EUROPY ŚRODKOWO-WSCHODNIEJ
}

\author{
MAŁGORZATA KORPAŁA ${ }^{1}$ \\ (Uniwersytet Kardynała Stefana Wyszyńskiego w Warszawie)
}

Słowa kluczowe: konserwacja zabytków, rekonstrukcja, dziedzictwo kulturowe

Key words: conservation of monuments, reconstruction, cultural heritage

\begin{abstract}
Abstrakt: Małgorzata Korpała. O NOWEJ KREACJI ZABYTKÓW, CZYLI W POSZUKIWANIU WYIDEALIZOWANEJ WIZJI PRZESZŁOŚCI EUROPY ŚRODKOWO-WSCHODNIEJ. „PORÓWNANIA" 17, 2015. T. XVII. S. 105-122. ISSN 1733-165X. Po odzyskaniu niezależności przez państwa Europy Środkowo-Wschodniej ochrona zabytków stała się częścią nowej retoryki historycznonarodowej. W artykule omówione zostały przykłady rekonstrukcji i kreowania zabytków po 1989 roku w Polsce, na Litwie oraz na Ukrainie. W zabytkach kodowane są nowe współczesne treści ideowe i stają się one ważnym czynnikiem współczesnych procesów gospodarczych, społecznych i narodowych. Rekonstrukcje po 1989 roku należy odczytywać jako realizację współczesnej polityki ubranej w symbole historyczne. Ingerencje w tkankę zabytku są podyktowane dążeniem, by utracone dziedzictwo po rekonstrukcji było jeszcze wspanialsze niż przed zniszczeniem.
\end{abstract}

Abstract: Małgorzata Korpała. ABOUT A NEW CREATION OF MONUMENTS - IN SEARCH OF NON-EXISTENT VISION OF PAST IN CENTRAL-EASTERN EUROPE. "PORÓWNANIA" 17, 2015. Vol. XVII. P. 105-122. ISBN 1733-165X. After the reclaim of independence by countries of the Central-Eastern Europe, the issue of protection of monuments became a part of the new historic and national rhetoric. This article shows examples of the reconstruction and creation of monuments after 1989 year in Poland, Lithuania and Ukraine. New contemporary ideas are encoded in the monuments and subsequently they become important factors shaping present day economy, society and nations. Reconstructions after 1989 have to be interpreted as the reali-

\footnotetext{
${ }^{1}$ Correspondence Address: mkorpala@wp.pl
} 
sation of contemporary politics adorned with historic symbols. Interventions in the architecture of the monuments result from the need to restore the lost heritage to much fuller glory than had even existed before its destruction.

Odzyskanie niezależności przez państwa Europy Środkowo-Wschodniej po 1989 roku znalazło swój wyraz nie tylko w przemianach gospodarczych i społecznych, ale i w innych dziedzinach życia. Jedną z nich była zmiana podejścia do ochrony zabytków, które stanowiło część szeroko propagowanej retoryki historyczno-narodowej. Zastąpiła ona ideologię komunistyczną i stanowiła komponent nowej wizji przeszłości i teraźniejszości. Historia polityczna XIX i początku XX wieku zaowocowała też przeświadczeniem, że jedyną drogą ocalenia tożsamości i odrębności państwowej jest odrzucenie tego, co jej zagraża. Odnosiło się to przede wszystkim do uznawanego za "obce” dziedzictwa kulturowego. Poprzez zabytki kreowano wyidealizowany obraz przeszłości sprowadzając ją do zmagania się $\mathrm{z}$ „wrogimi” siłami i ościennymi sąsiadami, by chronić własną ojczyznę. Nową wizję przeszłości można więc rozumieć jako idealizowanie historii poprzez eksponowanie wątków narodowych i poprawianie przekazu historycznego. Poszczególne społeczeństwa szukały własnej drogi manifestowania przeszłości zgodnej $\mathrm{z}$ ich aspiracjami narodowymi.

\section{Powojenne odbudowy zabytków jako nowa kreacja}

Przed 1989 rokiem działania podejmowane wobec zabytków były uwarunkowane interesem publicznym i potrzebą "odzyskania" dla narodu zabytków zniszczonych na skutek działań II wojny światowej. Zabytki były nie tylko materialnym dokumentem i świadectwem historii narodowej, ale przed wszystkim jej symbolem. Przypisana im misja społeczna polegała na konsolidacji wokół historii narodowej, jako ważnej osi kształtowania nowoczesnego państwa. Wizje przeszłości w poszczególnych krajach Europy Środkowej różniły się, gdyż każdy z narodów idealizował ją i poprzez zachowane zabytki starał się gloryfikować własną narodową historię. Prowadziło to do zacierania wielokulturowości z bogactwem, ale i trudną do zaakceptowania różnorodnością religijną, etniczną oraz rozwarstwieniem społeczno-klasowym.

Po zakończeniu II wojny światowej zabytki pełniły szczególną rolę, co trafnie skomentowali m.in. Greg Asworth, Ján Bakoš oraz Joseph Rykwert, którzy podkreślili ich instrumentalizację w społeczeństwach totalitarnych (Ashworth 57-66; Bakoś 108-119; Rykwert 198-201). Zabytki stały się elementem służącym nowemu 
ustrojowi i podbudowującym nową wizję społeczeństwa. Także odbudowa wielu polskich miast - takich jak np. Lublina, czy Warszawy (Martyn 270-289; Markiewicz 179-189; Sujecki 190-202; Majewski, Markiewicz; Mangelowa 141-142) - była wykorzystywana przez władze, a jej celem było nie tylko podniesienie $\mathrm{z}$ ruin, ale także zjednanie społeczeństwa i zaangażowanie go do służby na rzecz nowego ustroju. Podejmowanym odbudowom zabytków architektury i układów urbanistycznych historycznych ośrodków miejskich przyświecało pragnienie przekazania kolejnym pokoleniom zabytków nie $\mathrm{w}$ takiej formie jak przed ich zniszczeniem, ale piękniejszych i wspanialszych niż dawniej (Romejko- Hurko 26-32). Restauracja, a także rekonstrukcja dawała szansę na kontynuację istnienia wszystkich niematerialnych wartości i idei jakie się z nimi łączyły, mimo, że substancja materialna zabytku nie była autentyczna. Szczególnym przykładem była odbudowa warszawskiej starówki oraz restytucja Zamku Królewskiego w Warszawie traktowanego w symboliczny sposób jako odzyskiwanie historii i kultury polskiej zniszczonej na skutek wojny. Odtworzenie zamku było wzorcowe poczynając od przygotowania projektu odbudowy, w którym założono wykorzystanie wszystkich zachowanych reliktów (zarówno murów jak i ocalonych i zabezpieczonych elementów wystroju), a jednocześnie stanowiło materializację społecznych oczekiwań, nadziei i marzeń (Lorentz 2-3; Zachwatowicz 1972: 194-196; Zachwatowicz 1973: 13-19; Zachwatowicz 1979: 3-17). Ważne było też kreowanie funkcji zabytków w kontekście społecznych oczekiwań. Po II wojnie światowej władza poprzez zaplanowaną i dość konsekwentnie realizowaną politykę odbudowy kraju kształtowała nastawienie społeczne wobec zabytków (Miłobędzki 1994: 131-141; Miłobędzki 1995: 22-24; Miłobędzki 1996: 17-20). Odbudowa kraju była także elementem kształtowania ideologii socjalistycznego państwa - w której zlikwidowano własność znosząc nierówności i niesprawiedliwości społeczne, a wszystko w tym zabytki stały się wspólnym dobrem. Socjalistyczna ideologia miała niemały wpływ na praktykę odbudowywania zabytków, wprzęgając je „w służbę wielkich wizji historycznych" (Miłobędzki 2012).

Polityka opieki i konserwacji zabytków była realizowana przez środowisko konserwatorów, architektów oraz historyków sztuki. Dawało to szansę na wdrażanie teorii i doktryn konserwatorskich, które mimo częściowej izolacji politycznej PRL-u były kształtowane na forum międzynarodowym także przez polskie środowisko konserwatorskie (Szmygin). Środowisko to miało świadomość społecznej misji. Poprzez decyzje o zakresie ingerencji w zabytek - zwłaszcza, gdy podejmowano rekonstrukcje - kształtowano oddziaływanie zabytków na odbiorców. W ten sposób kreowano oczekiwania społeczne, co tego jaką rolę winien pełnić zabytek i jak powinien wyglądać. Funkcja zabytków była ściśle powiązana z możliwością ich wykorzystania do potrzeb współczesnego życia i kształtowała się wokół haseł: "Zabytki w służbie przyszłości” oraz „Zabytki w służbie społeczeństwa” (Ptaś- 
nik 3-5). W wyglądzie zabytku akcentowano przede wszystkim odniesienie do chlubnej przeszłości narodowej, a także przenoszenie idei związanych z historią kraju poprzez walory estetyczne i artystyczne.

\section{Zabytki jako przejaw kreowanej przeszłości}

Po II wojnie światowej zabytki stanowiły ważne medium budowania tożsamości narodowej. Było to bardzo ważnym zadaniem nowej władzy w obliczu dość krótkiej w XX wieku historii niepodległości kraju, a także nowych granic politycznych ustalonych na mocy postanowień konferencji poczdamskiej. Migracja oraz planowe akcje przemieszczania ludności polskiej z Kresów na obszary Dolnego Śląska, Śląska Opolskiego, Pomorza Zachodniego oraz Warmii i Mazur nazwane eufemistycznie "Ziemiami Odzyskanymi" spowodowały, że dla nowych mieszkańców obszary te były obce kulturowo, a często także cywilizacyjnie (Lubocka-Hoffman). Droższa im była ojcowizna, którą musieli opuścić, niż to co zasiedlili i co ich na co dzień otaczało. Ta trudna sytuacja społeczno-polityczna sprawiała, że $w$ okresie powojennym koncentrowano się na reliktach związanych z początkami państwa Piastów, z pominięciem a tym samym często z przyzwoleniem na zaniedbanie i zniszczenie tego, co było dziedzictwem kultury niemieckiej uznanej za obca, a nawet wrogą. Takie zabytki były niechcianymi znakami pamięci i dlatego na tych obszarach raczej zacierano, czyli przekształcano lub nawet wyburzano zamiast chronić. Mimo, że postulaty odbudowy zniszczonych miast na Ziemiach Odzyskanych formułowano już pod koniec lat 40. XX wieku, jeszcze przez wiele lat później zgadzano się na przebudowę zniszczonych miast bez poszanowania zastanych zabytków, nawet gdy odbudowa była możliwa. Los ten spotkał dziesiątki śląskich miast, nawet tych najstarszych i wiązanych z polskością - przykładowo w Nysie nazywanej śląskim Rzymem i wiązanej z działalnością jednego z Wazów rozebrano liczne kamienice, aby w tym miejscu wznieść współczesną zabudowę blokową. Także i później, bo od końca lat 70. XX na miejscu rozebranych kamienic zaczęto budować nowe budynki nawiązujące jedynie bryłą i materiałem do poprzednich i było to jedynym już wówczas możliwym sposobem przywołania stanu sprzed zniszczenia, nazwanym wówczas retrowersją - np. Elbląg, Szczecin (Podlewski 110-114; Rymaszewski 1995; Lubocka-Hoffmann, Gierlasiński 565-591). Przedmiotem ochrony było przede wszystkim to, co realizowało wytyczone cele, jakim było państwo narodowe, rozumiane jako zamieszkane przez Polaków. Pomijano dziedzictwo nie związane z polską kultura i historią - szczególnie na obszarach Ziem Odzyskanych, gdzie doświadczenia II wojny światowej powodowały niechęć wobec wszystkiego, co obce. Nie tylko nie chroniono, ale wręcz niszczono to, co było "znakiem pamięci” o dawnych mieszkańcach innych nacji czy religii. Nierzadkie były rozbiórki, przekształcanie funkcji poprotestanckich kościo- 
łów czy nawet likwidacje „poniemieckich” cmentarzy. Działania te podejmowano przez wiele lat, a na największą skalę na początku lat 70. - np. likwidacja cmentarza ewangelickiego wokół Kościoła Pokoju w Jaworze, który przy akceptacji urzędu konserwatorskiego zamieniono na park miejski na początku lat 70. XX wieku. Zmiana mentalności społecznej wynikająca z refleksji, że nie da się całkowicie zatrzeć prawdziwej historii, nastąpiła dopiero po transformacji ustrojowej.

Asymilacja nowych mieszkańców odbywała się więc poprzez eksponowanie wszystkiego, co potwierdzało powrót tych "ziem odzyskanych" do "macierzy". Dla władzy był to klucz do legitymizacji przejęcia tych terenów, a jednocześnie do scalenia obywateli wokół jednej tożsamości narodowo-historycznej. Zabytki stały się symbolami przywołującymi historię. Ich wygląd stał się nośnikiem określonych treści i idei, a w związku z tym to wygląd determinował dostępność przekazu kierowanego do odbiorców. Zabytek zniszczony stanowił „memento”. Zabytek odrestaurowany stawał się już nie dokumentem historii, lecz sugestywnym i realnym nośnikiem wiedzy o przeszłości. Wartości, które wyrażał oryginał były przenoszone na nowe dzieło, tak jakby ono stanowiło jego bezpośrednią kontynuację. Uzasadnienie tych działań stanowiła doktryna konserwatorska akceptująca, że zmiany jakie zaistniały w zabytku (przebudowy, zmiany wystroju dekoracyjnego, czy też zniszczenia wynikające $\mathrm{z}$ upływu czasu oraz wydarzeń politycznych na przestrzeni dziejów) odzwierciedlały przemiany społeczne i kulturowe (Rymaszewski 2002). Jednocześnie doktryna ta uwzględniała potrzebę estetyzacji pozwalając na uzupełnienie zniszczonych fragmentów, a nawet na całkowite odtworzenie dzieła zniszczonego, gdy pełniło ono ważną funkcję kulturową, społeczną lub religijną. Zniszczonemu zabytkowi należało więc "przywrócić dawną świetność" aby podtrzymać jego dotychczasową symboliczną funkcję. Ten „prawdziwy” wygląd odzyskiwano poprzez usunięcie późniejszych nawarstwień i pozostawienie uznanych za najcenniejsze najstarszych fragmentów budowli, a także poprzez odtworzenie i odbudowę ze zniszczeń. Odbudowa obejmowała często zmiany wprowadzane w zabytkach, by "nabrały nowego wyrazu” poprzez nadanie im nowych treści. W praktyce polegało to na usuwaniu religijnych dekoracji z elewacji lub zastępowanie ich świeckim programem (Majewski, Markiewicz 135-138). Przy odtwarzaniu nieistniejących już elementów często stosowano formy historyczne, gdyż $\mathrm{w}$ ten sposób zakres ingerencji był ściśle uwarunkowany wiedzą o historycznym wyglądzie zabytku. Zabytek odzyskiwano zarówno w sensie materialnym (bo ponownie zaistniał, lub mimo zniszczeń stawał się kompletny), jak i w sensie duchowym. Nadal jego wygląd pozwala go traktować jako symbol danej epoki, czy też jako dokument przeszłości. Po przeprowadzeniu restauracji lub rekonstrukcji zabytek był materializacją wyobrażenia wspartego starannie wyselekcjonowaną wiedzą. A jednocześnie stał się on modelowym typem - swoistym pomnikiem. Zabytki miały włączyć się w życie społeczeństwa socjalistycznego, co powodowało ich "poprawianie” i korygowanie nie tyle w myśl doktryn konserwa- 
torskich, co raczej potrzeb użytkowych (np. całkowite przekształcenie układu funkcjonalnego wnętrza i pozostawienie jedynie fasady, która nadaje budowli walor autentyzmu) (Tomaszewski 291-295).

Drugim istotnym wpływem ideologii socjalistycznej było „programowe” odcinanie się od potrzeby objęcia ochroną dworów i pałaców, które mimo działań wojennych przetrwały $\mathrm{w}$ dobrym stanie. Takie zabytki także były niechcianymi dowodami innej rzeczywistości, całkowicie zanegowanej w ustroju socjalistycznym. Były one przejmowane na cele użyteczności publicznej (szkoły, urzędy itp.) lub funkcjonowały do końca lat 80. XX jako siedziby PGR-ów. Pragmatyzm tego utylitarnego podejścia zacierał prawdziwą historię i tworzył nową teraźniejszość łudząc, że jest ona „lepsza” i bardziej sprawiedliwa społecznie.

\section{Kreacja przeszłości, czyli rekonstrukcje zabytków po 1989 roku}

Po transformacji można zaobserwować zmianę nastawienia polegającą na poczuciu zakorzenienia i akceptacji „obcych” zabytków. Zmianę można zaobserwować dopiero $\mathrm{w}$ trzecim pokoleniu, które w dorosłe życie weszło w okresie transformacji ustrojowej. Zaczęto wówczas na nowo odkrywać wielokulturowe dziedzictwo, ale sposobem jego akceptacji była stopniowa aneksja obcego kulturowo dziedzictwa. Po transformacji ustrojowej mimo tego, że doktryny konserwatorskie zasadniczo nie uległy zmianie, nadal można zaobserwować w podejściu do zabytków wyidealizowane postrzeganie przeszłości. Zabytek nadal musi być nośnikiem idei „chlubnej przeszłości”, która jest uwznioślana. W tym czasie dominuje romantyczne widzenie przeszłości operujące stylizacją historyczną i aranżacjami uzupełniającymi historyczne kompozycje wystroju.

Rekonstrukcje zabytków - czy też ich fragmentów - przybierają zazwyczaj odpowiednio dopasowane do oryginału formy historyzujące. Jest to świadome naśladowanie, a nawet imitowanie historycznego stylu. Jedną $\mathrm{z}$ ostatnich jest wrocławska kaplica Hochberga przy kościele Św. Wincentego, gdzie dokonano rekonstrukcji zniszczonego w czasie działań wojennych wystroju sztukatorskiego oraz malowideł na sklepieniu (Kaplica Hochberga). Jeśli brakuje informacji i archiwalnych ilustracji dokumentujących jak zabytek wyglądał przed zniszczeniem, jedyną możliwością jest aranżacja, która scala i uzupełnia kompozycję. Jest to ważne przede wszystkim dla estetyki zabytku (odzyskania kompletnego, harmonijnego dzieła). Aranżacja taka była ściśle związana z dążeniem do przywrócenia funkcji użytkowej zabytku. Wpisuje się $\mathrm{w}$ to estetyzacja - np. wypełnienie barwne pól po zniszczonych malowidłach tak, by zachować lub zasygnalizować akcenty pierwotnej kompozycji wystroju. Zasadniczym celem współcześnie podejmowanych rekonstrukcji zabytków jest więc szukanie nowej tożsamości nawiązującej do 


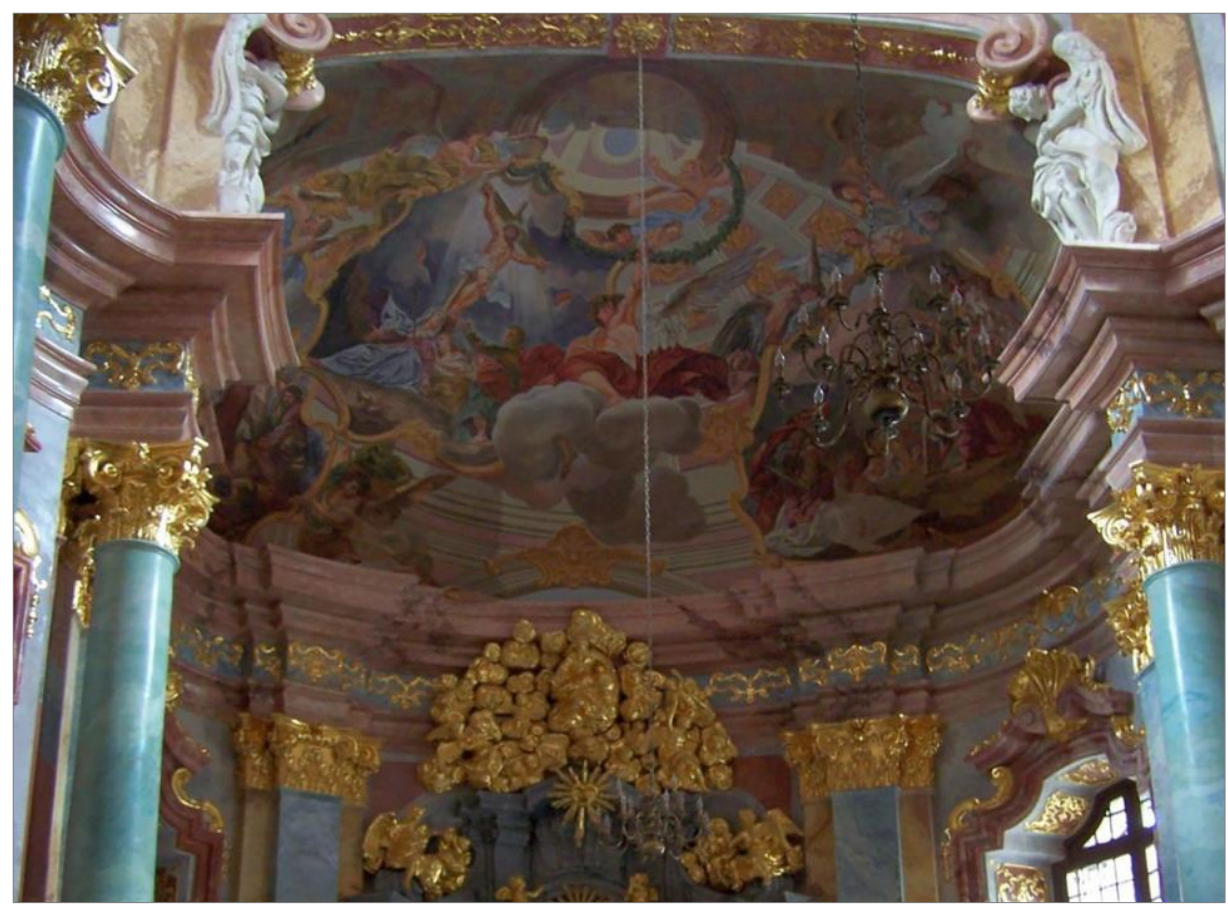

Wrocław, kaplica Hochberga, wnętrze po rekonstrukcji wystroju sztukatorskiego i polichromii, fot. M. Korpała 2013

tradycji (np. religijnej), jako szansy na poszukiwanie współczesnych dróg widzenia przeszłości.

Analogiczne tendencje występują $\mathrm{w}$ krajach sąsiednich np. odbudowa cerkwi na Ukrainie (Gerycz 7-15; Komar 160-165). W latach 30. XX wieku niszczenie, wysadzanie i rozbieranie świątyń przez władze było jednym z elementów zmierzających do wykorzenienia religii. W latach 90. XX wieku możliwe było odtworzenie niektórych z nich. Stały się one nie tylko miejscem kultu, ale symbolem odrodzenia narodu. Po odzyskaniu niepodległości przez Ukrainę ich odbudowa była wspierana finansowo przez nową władzę. Reguły, według których podejmowano rekonstrukcje były zróżnicowane i opierały się nie tylko na obowiązujących doktrynach i teorii konserwacji. Zniszczoną przez bolszewików klasycystyczną Cerkiew Narodzenia Pańskiego w Kijowie z początku XIX odtworzono na podstawie archiwalnych projektów (od 2004 roku użytkowana przez Ukraiński Kościół Prawosławny Patriarchatu Moskiewskiego). Podobne rozwiązanie zastosowano w kompleksie Monastyru św. Michała Archanioła o Złotych Kopułach (pierwszy na Rusi ze złotymi kopułami), który został pieczołowicie odbudowany za czasów niepodległej Ukrainy, a fragmenty oryginalnej świątyni są eksponowane, jako relikty na dziedzińcu. 


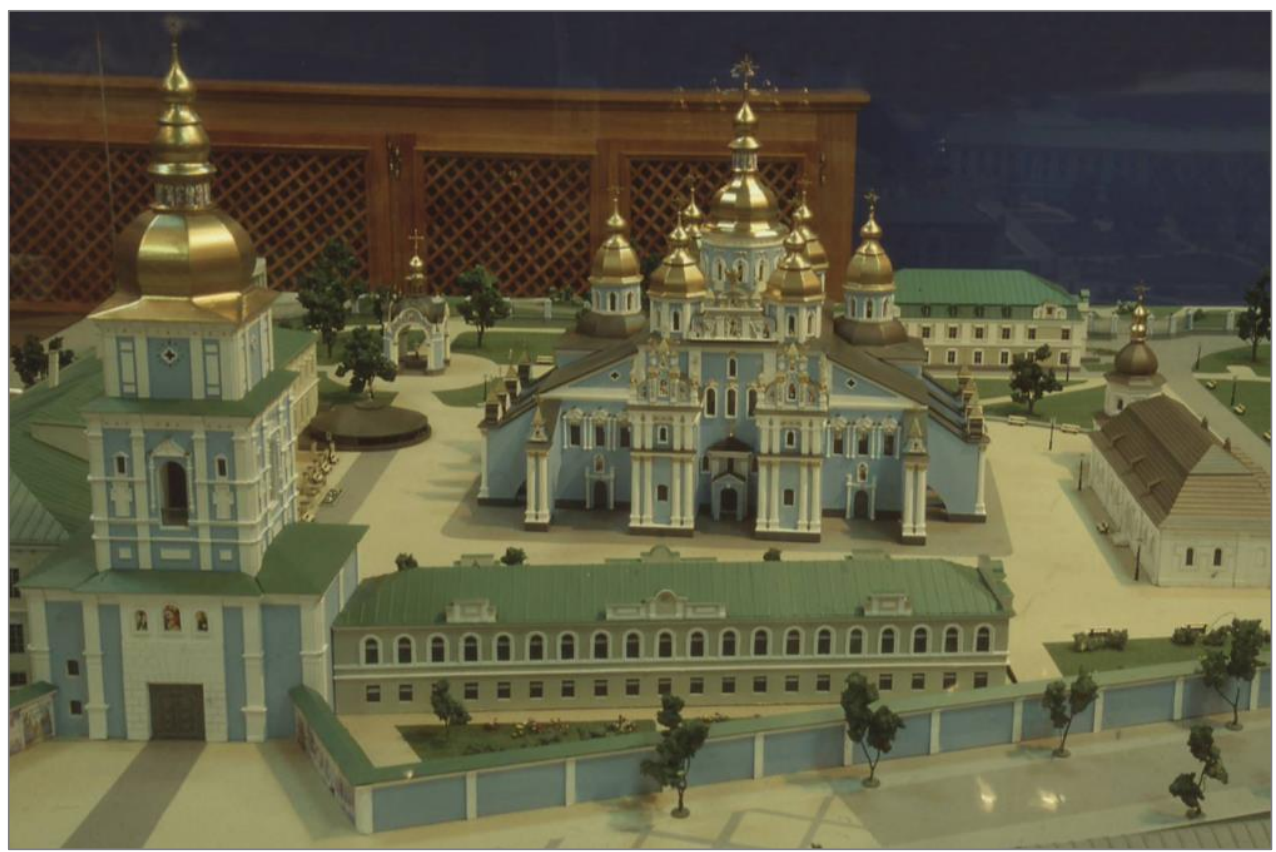

Kijów, Monastyr św. Michała Archanioła o Złotych Kopułach - stan po odbudowie i rekonstrukcji, fot. J. Lewicki 2008

Skrajnie odmienne decyzje podjęto przy odtworzeniu cerkwi Spotkania Pańskiego w Kijowie, której początki były związane z wielkim księciem Rusi Kijowskiej Jarosławem Mądrym (Aleksejczuk). Wielokrotnie przebudowywana świątynia zyskała w połowie XIX wieku oprawę w stylu neobizantyjskim. Do zburzenia w latach 30. XX wieku było to nie tylko miejsce kultu religijnego, ale także ważne i symboliczne miejsce działań społecznych (szkoły, jadłodajnia). Ta wartość symboliczna w trakcie podejmowania odbudowy w latach 90. XX wieku przeważyła nad wartością zniszczonej historycznej formy. Postanowiono więc nie odwoływać się do żadnego z zachowanych historycznych projektów cerkwi, lecz opracować współczesny projekt - konstrukcję ze szkła. Nowa cerkiew ma być jak dawniej dominantą rekonstruowanego placu.

\section{Kreowanie nowych zabytków po 1989 roku w ramach obchodów jubileuszowych rocznic}

Po 1989 roku, gdy państwa Europy Środkowej i Wschodniej odzyskały niezależność polityczną czy też niepodległość (jak Litwa czy Ukraina), można zauważyć szczególne podejście do ochrony zabytków. Obok prac o charakterze stricte kon- 
serwatorskim podejmowane były kreacje a nawet odbudowa wybranych zabytków. Celem podejmowanych rekonstrukcji było dążenie, aby utracone dziedzictwo mogło się odrodzić jeszcze wspanialsze niż przed zniszczeniem. Rekonstrukcja zabytku stała się narzędziem do kreowania współczesnego spojrzenia na historię, co stało się powszechne nie tylko w Polsce, ale także w innych krajach Europy Środkowej. Przykładem jest odbudowa Dolnego Zamku w Wilnie, którego oficjalna nazwa brzmi dziś Pałac Władców Litwy. Stojąca w tym miejscu budowla była pierwotnie siedzibą Wielkiego Księcia Giedymina, zaś w późniejszym czasie rezydencją książąt Wielkiego Księstwa Litewskiego oraz królów Rzeczpospolitej. Zniszczenia zamku w wyniku wojen szwedzkich, doprowadziły na początku

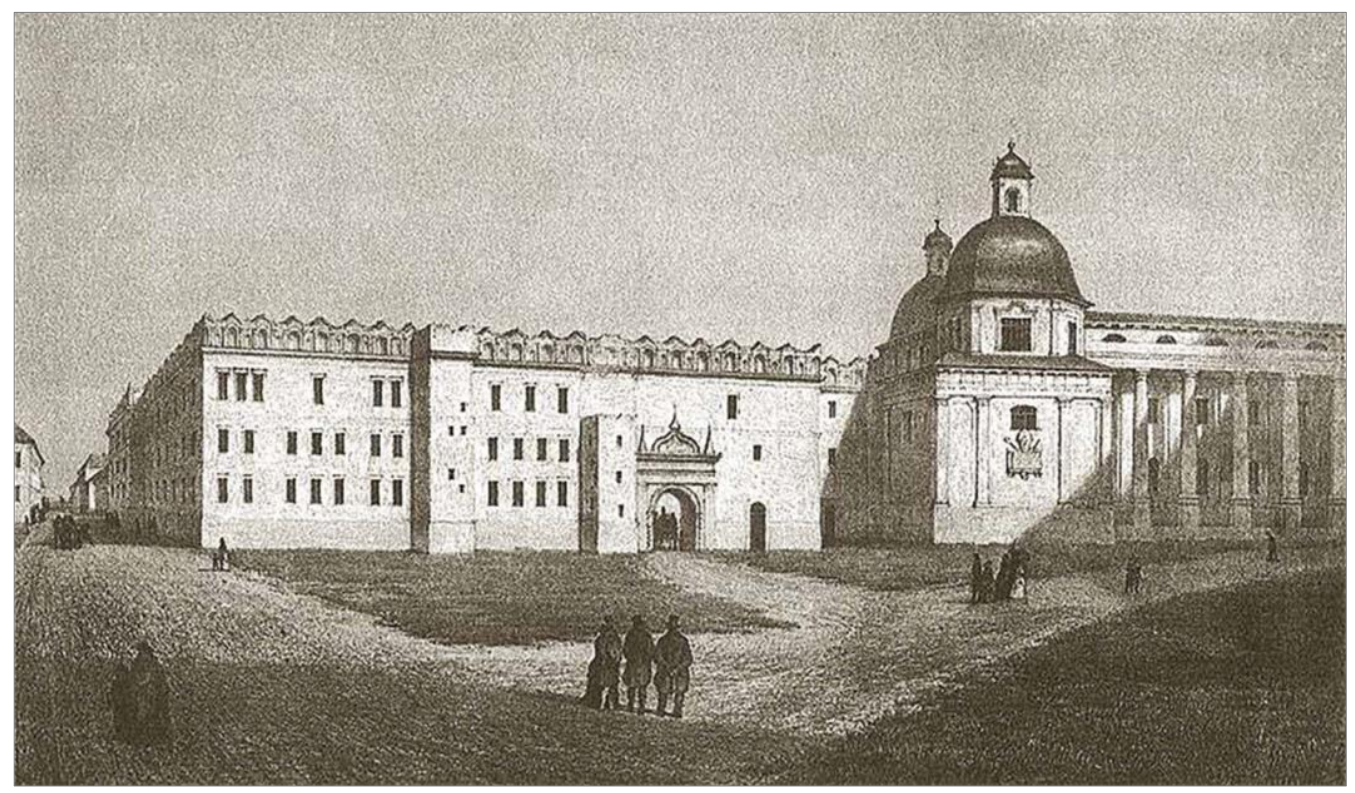

Wilno, Zamek Dolny: widok historyczny, rycina Napoleon Ordy z 1793 r.

XIX wieku do podjęcia decyzji o jej wyburzeniu. Zamiar odbudowy wileńskiego zamku z przeznaczeniem na siedzibę władz (prezydenta) oraz funkcję muzealną, władze wolnej Litwy ogłosiły niemal dwa wieki później, pod koniec lat 90. XX w. Odbudowę przeprowadzono $\mathrm{w}$ latach 2002-2013, ale symboliczne otwarcie nastąpiło w już 2009 roku w związku z obchodami Milenium Litwy (pierwszej historycznej wzmianki). Odbudowa ta wzbudziła duże kontrowersje zarówno w społeczeństwie, jak i wśród historyków. Mimo, że uznano ją za romantyczny gest to olbrzymie koszty i brak dokładnych materiałów źródłowych sprawiły, że jest 


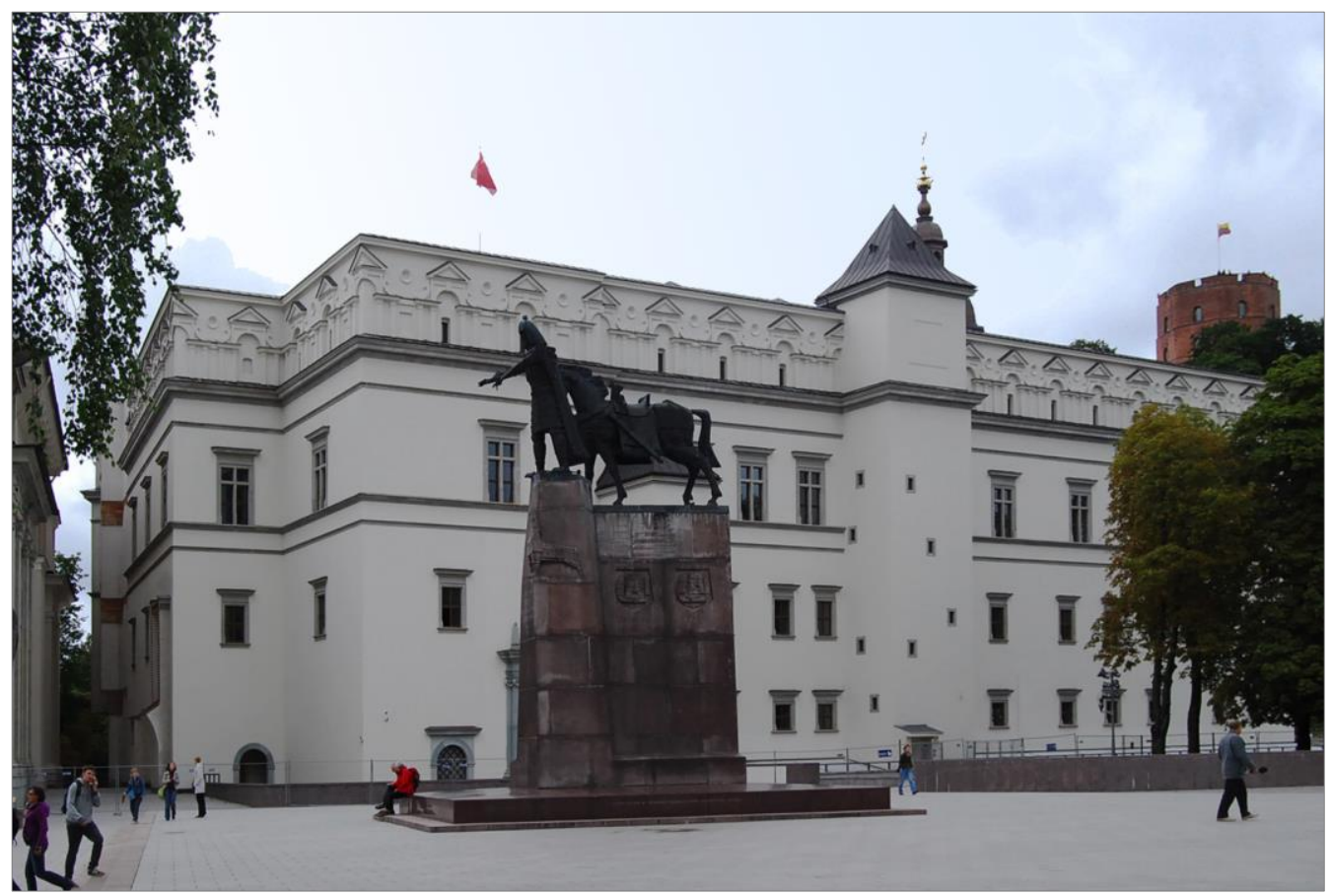

Wilno, Zamek Dolny: widok po odbudowie na pocz. XXI wieku, fot. J. Lewicki 2012

to rodzaj konserwatorskiej kreacji a nie sensu stricto rekonstrukcja. Architekci bardzo swobodnie wzorowali się na przekazach historycznych, co sprawia, że dzisiejszy wygląd zamku jest efektem realizacji współczesnych koncepcji ideowych i funkcjonalnych. Przede wszystkim zmieniono proporcje bryły, tak by zamek dominował nad zabytkową klasycystyczną katedrą. Mimo przeprowadzenia badań archeologicznych i korzystania z archiwalnych rycin i materiałów ikonograficznych, po odbudowie zmieniono wiele elementów architektonicznych (np. zwieńczenie attyk jest niezgodne z zachowanymi archiwalnymi widokami i zastosowano nowe dekoracje $z$ etnicznymi litewskimi motywami). W miejscu dawnego godła Rzeczpospolitej obojga narodów (Orzeł i Pogoń) odnoszącego się do wielokulturowości i wielojęzyczności historycznej Litwy pozostawiono tylko litewską Pogoń. Odbudowa zamku wileńskiego może nasuwać skojarzenie z odbudową Zamku Królewskiego w Warszawie. Jednakże mimo podobieństw polegających na potrzebie odzyskania ważnego dla społeczeństwa symbolu narodowego zasadnicza różnica tkwi w wierności wobec utraconego pierwowzoru. Zamek warszawski był rekonstruowany bardzo pieczołowicie i właśnie ta wierność odtwarzania zasadniczo odróżnia go od odbudowy, a raczej dość swobodnej neokreacji zamku wileńskiego. 


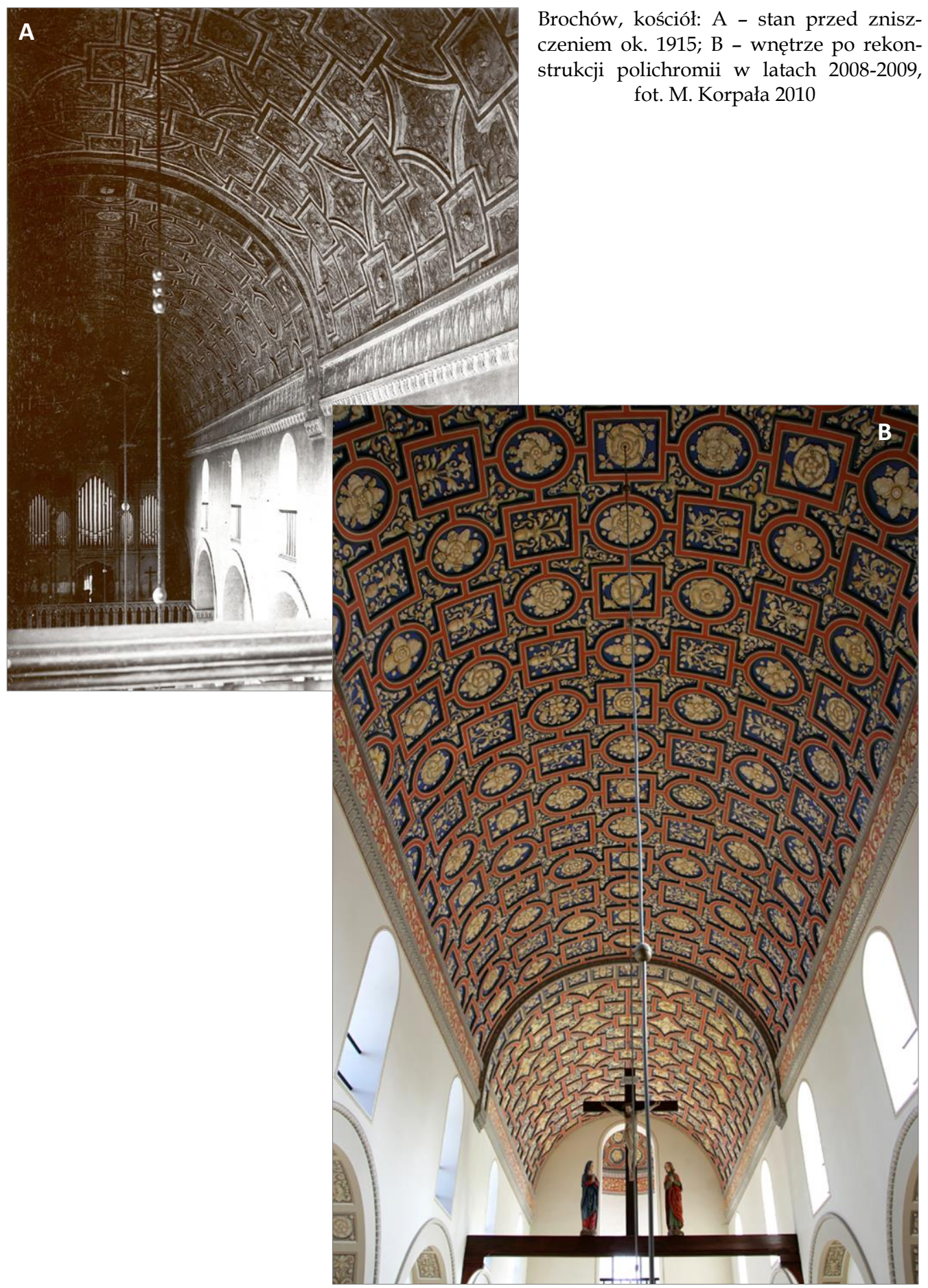


Odpowiednikiem powyższych działań w Polsce były realizacje związane z obchodami jubileuszu 200-lecia urodzin Fryderyka Chopina. Wydarzenia kulturalne poświęcone temu kompozytorowi, poprzedziły rekonstrukcja wystroju w kościele w Brochowie (miejsca chrztu Chopina) oraz gruntowna modernizacja i rozbudowa muzeum Chopina w Żelazowej Woli (miejsca urodzenia). W tym samym czasie podejmowano zupełnie odmienne decyzje $\mathrm{w}$ zakresie działań służących do upamiętnienia tego ważnego wydarzenia. Renesansowy kościół w Brochowie został ostrzelany w trakcie wojennych działań w 1915 roku (fot. A). Odbudowa 1924-1929 według projektu Jarosława Wojciechowskiego i Tymoteusza Sawickiego z wprowadzeniem elementów modernistycznych nie objęła jednak odtworzenia wystroju malarskiego zawalonych sklepień, ani zniszczonego wyposażenia ruchomego (Zamecznik). Rekonstrukcje przeprowadzono dopiero w latach 2008-2009 w oparciu o materiały archiwalne i odkrywki zachowanych fragmentarycznie polichromii malarskich (fot. B). Natomiast wyposażenie ruchome odtworzono w duchu historycznym. Celem podjętych prac było przywrócenie dawnego wyglądu sprzed zniszczenia dla podniesienia rangi tego miejsca jako symbolu historycznego. Z kolei Muzeum w Żelazowej Woli zostało wykreowane w latach 30. XX wieku -

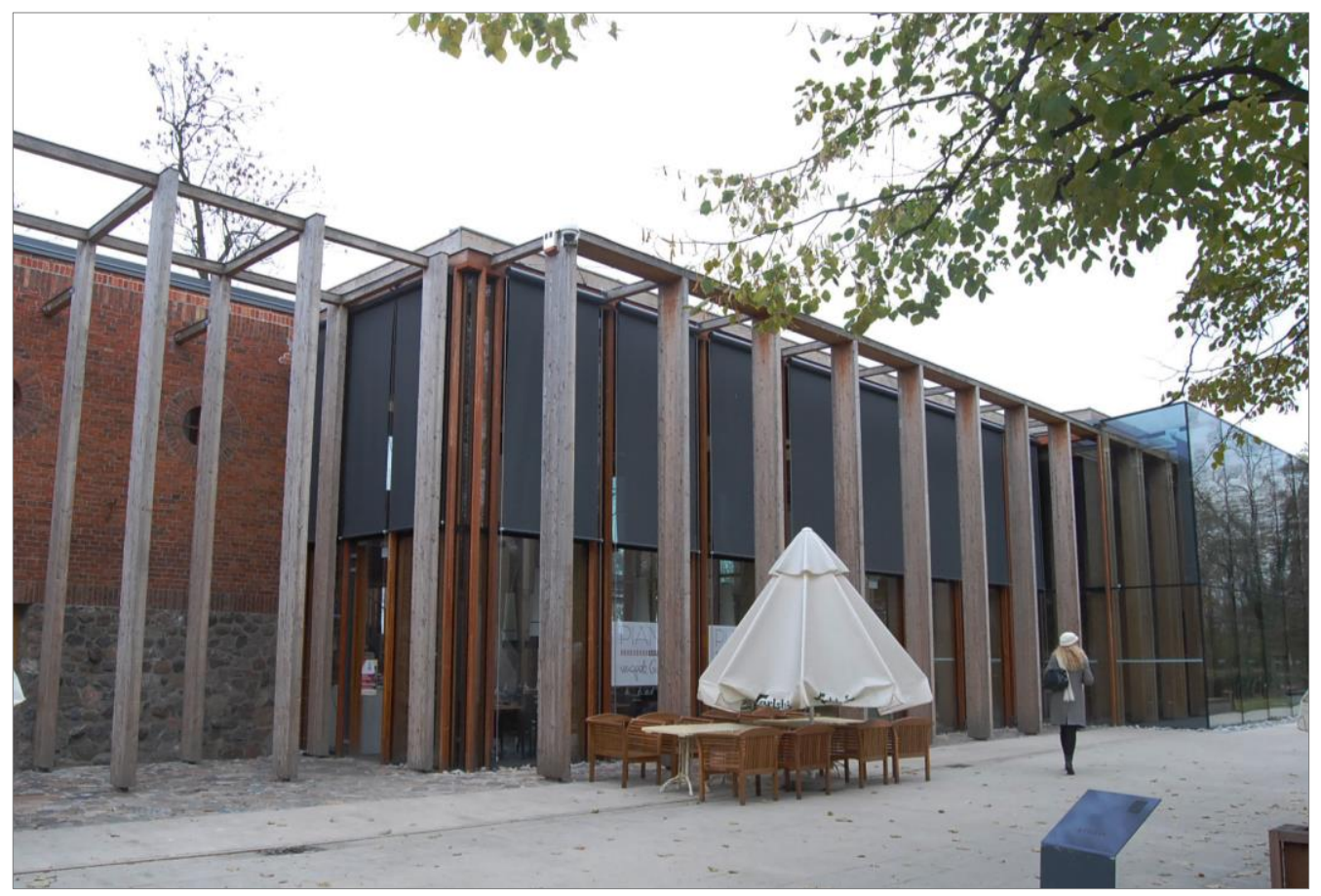

Żelazowa Wola, Muzeum Chopina, stan po rozbudowie w 2010 r. - nowe pawilony na terenie parku, fot. M. Korpała 2010 
począwszy od przebudowy domu na dwór, aż po aranżację otoczenia, jako parkupomnika z nasadzeniami darowanych roślin z całego świata. Była to realizacja dla upamiętnienia Chopina, wielki pomnik narodowy, a nie oddanie historycznej prawdy tego miejsca. Nieprzemijająca popularność kompozytora spowodowała, że muzeum stanęło przed koniecznością modernizacji ułatwiającej obsługę turystów i melomanów. Działania te wykraczały jednak poza dobudowę dodatkowych budynków. Uznano, że należy usunąć historyczną aranżację oddającą styl wnętrz XIX-wiecznych, wstawiając w zamian współczesne graficzne symbole, które tylko $\mathrm{w}$ warstwie semantycznej odwołują się do czasów życia Chopina. Zamysłem takiego świadomego zaniechania rekonstrukcji było wyeksponowanie nowoczesnej wizji przeszłości. Jednakże ta de facto próba ucieczki od romantycznego postrzegania historii jest jej nową kreacją. Obydwie realizacje były klasycznym wymyśleniem nowej wizji zabytku: kościół w Brochowie stal się piękniejszy niż za czasów Fryderyka Chopina, a oryginalny ogród-pomnik w Żelazowej Woli unowocześniono i pozbawiono większości oryginalnych pomnikowych roślin i elementów cennego modernistycznego wystroju zaprojektowanego przez architekta Franciszka Krzywdę-Polkowskiego.

\section{Wyidealizowana wizja Europy a społeczeństwo}

Trudno jednoznacznie stwierdzić czy rekonstrukcje zabytków są wynikiem zmiany społecznej i kulturowej (Kowalski; Billert 175-179; Łoziński 16-17), czy też to kreacje dały początek i impuls do zmian mentalności i oczekiwań społecznych funkcji które współcześnie powinny one pełnić. Tym bardziej, że poza wąskim gronem specjalistów te "nowe” zabytki są przyjmowane na ogół z aprobatą, a niekiedy wręcz entuzjastycznie. Po 1989 roku można zaobserwować zmianę „oczekiwań społecznych" wobec zabytków. Transformacja ustrojowa umożliwiła zmianę prawa własności. Dawni właściciele i ich potomkowie odzyskiwali swoje nieruchomości, a także nowi właściciele często kupowali opuszczone zabytki. Zapoczątkowało to wyraźny podział zabytków na prywatne i państwowe - należące do Skarbu Państwa i zwykle wykorzystywane do celów publicznych (działalność kulturalna, oświatowa, administracja publiczna). Szczególna sytuacja nastąpiła, gdy agencje państwowe (przede wszystkim Agencji Własności Rolnej Skarbu Państwa) pozbywały się po upadku PGR-ów budynków i nieruchomości objętych prawną ochroną konserwatorską. Szybko zaistniał rynek nieruchomości zabytkowych, który umożliwił nabywanie zabytkowych kamienic, rezydencji czy założeń pałacowo-parkowych. Zabytek przestał być tylko dokumentem i symbolem swojej epoki, a stał się nowym wyznacznikiem współczesnych procesów społecznych i ekonomicznych. W sensie społecznym umożliwiał błyskawiczny awans i podnosił prestiż właściciela. $W$ sensie ekonomicznym zabytek zaczął stawać się 
inwestycją. Najważniejszym celem podejmowanych działań związanych z remontem i konserwacją wcale nie było zachowanie zabytku dla następnych pokoleń (przy możliwie jak najmniejszej ingerencji w strukturę czy też wygląd), ale to estetyka i wartość zabytku była kluczem do oceny jego znaczenia i aranżacji konserwatorskiej. O ile przed transformacją ustrojową w 1989 roku, dążono do „odzyskania" pierwotnego bądź historycznego wyglądu sprzed zniszczenia zabytku, to współczesne czasy ujawniły dążenia do konserwatorskiej kreacji w duchu historycznym.

Po transformacji ustrojowej okazało się, że oczekiwania społeczne uległy zmianie. Zniknął problem nieutożsamiania z materialnym dziedzictwem miejsca. Pokolenia Polaków urodzonych w okresie PRL-u traktują miejsce, w którym żyją, jako własne, choć dostrzegają i doceniają inne historyczne wpływy kulturowe. Dokonała się tym samym zmiana polegająca na wysuwaniu wobec zabytków oczekiwań kulturotwórczych, jak i ekonomicznych. Dostrzeżono potencjał zabytków jako dodatkowego czynnika wspierającego współczesny rozwój gospodarczy kraju. Ten potencjał jest ściśle związany z wyglądem, a więc i kompletnością historycznych budowli oraz układów urbanistycznych. Konieczne było podejmowanie ich modernizacji oraz adaptacji do nowych funkcji dostosowując je do nowej rze-

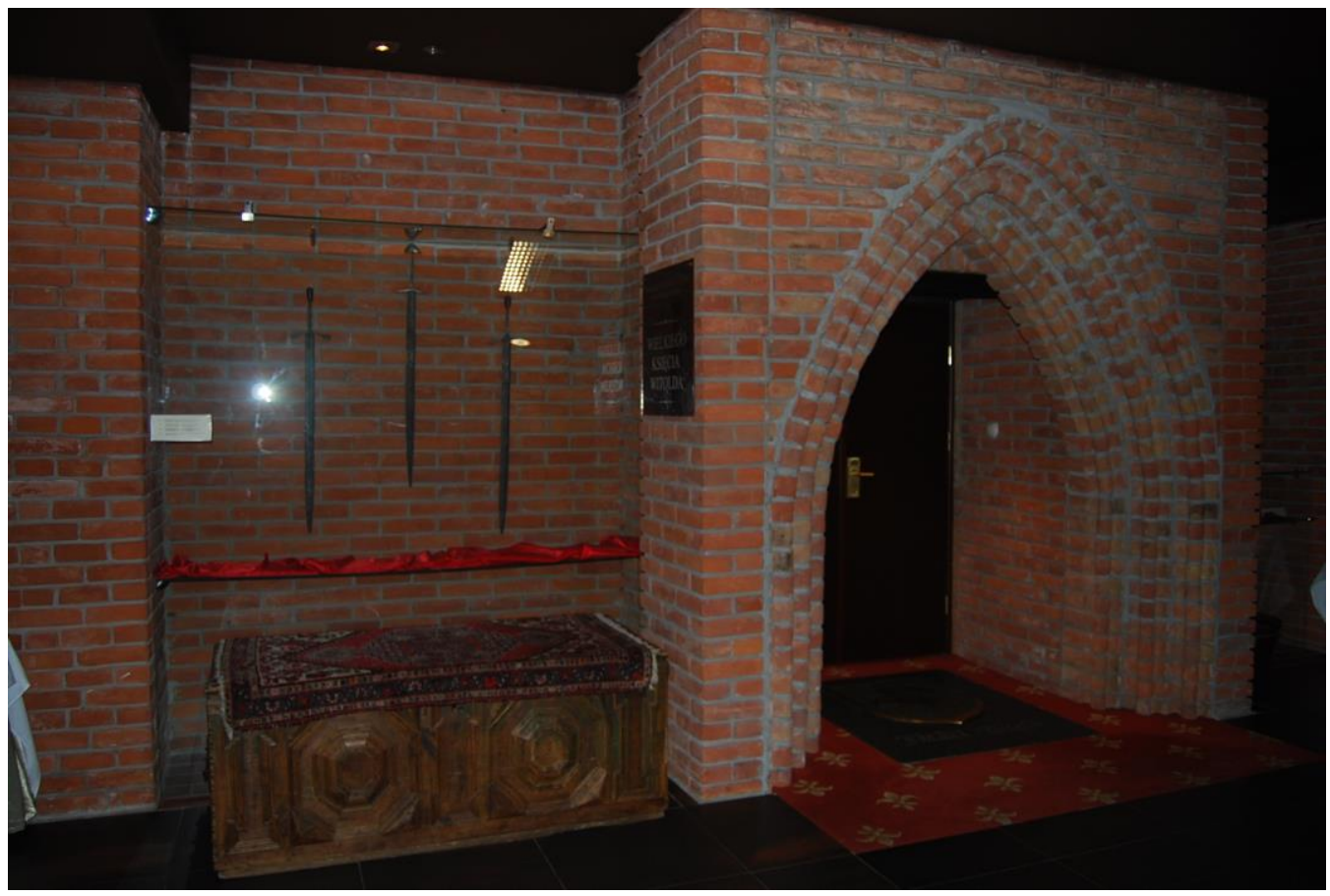

Zamek Ryn, adaptacja na hotel: ekspozycja na korytarzu w podziemiu, aranżacja korytarza na I piętrze, fot. M. Korpała 2009 
czywistości. Wiele zabytków architektury przekształcono na hotele oraz siedziby nowych prężnie rozwijających się firm oraz prywatne rezydencje. Zabytek zyskał nowe życie i nową funkcję dla społeczeństwa. Stał się wizytówką prestiżu społecznego. A ponadto coraz bardziej zaczął stawać się "produktem turystycznym" odgrywającym ważną rolę w rozwoju gospodarczym kraju (Kupisz). Kreacje odzwierciedlające romantyczne postrzeganie przeszłości to także realizacje prywatnych właścicieli podnoszenia z ruin średniowiecznych zamków. Odbudowany zabytek można użytkować i można podziwiać - staje się więc on atrakcją turystyczną, która na nowo buduje historię - np. zamek w Bobolicach (Guerquin; Mikołajski; Lasecki; Kadłuczka 1-85).

Interesującym przykładem ilustrującym zmianę $\mathrm{w}$ sposobie postrzegania roli zabytków jest Zamek Ryn, który obecnie pełni funkcję hotelu o wysokim standardzie. Jednakże zakres jego adaptacji wykracza poza dostosowanie do nowej funkcji. Sugestywność artefaktów imitujących zabytkowy wystrój i wyposażenie (np. drewniane elementy konstrukcyjne $\mathrm{z}$ rzeźbiarskimi przedstawieniami prasłowiańskich bóstw czy też ekspozycja kopii militariów średniowiecznej broni i wielkoformatowych reprodukcji historycznego malarstwa autorstwa Jana Matejki) sprawia, że są odbierane niemal tak samo jak elementy autentyczne (fot. 6).

\section{Podsumowanie}

W XX wieku zabytki były odzwierciedleniem postrzegania przeszłości w wyidealizowany sposób. Była to upiększona wizja jednolitego narodowo państwa o wspaniałej przeszłości, a zabytki miały potwierdzać rangę i znaczenie państwa. Kodowano nowe treści ideowe, które przez zabytki przenoszono i upowszechniano. Z przeszłości wybierano tylko te wątki, które mogły być pomocne w kreowaniu nowego spojrzenia na historię. Zabytki wykorzystywano do kształtowania i ugruntowania określonych postaw społecznych i kulturowych, a nade wszystko patriotycznych i narodowych. Stały się one narzędziem do konsolidowania społeczeństwa wokół uładzonej i uproszczonej wersji przeszłości z pominięciem elementów uznanych za niewygodne. Takie wyidealizowane spojrzenie zatarło i zafałszowało dowody wielokulturowości dziedzictwa, jak i trudne do zaakceptowania pomniki i ślady obcej dominacji.

Przemianom politycznym i ustrojowym po 1989 roku towarzyszyła zmiana mentalności społeczeństwa. $W$ odniesieniu do zabytków wiele zjawisk, które miały miejsce $\mathrm{w}$ tym okresie, stanowiło kontynuację okresu poprzedniego. Podejmowane wówczas rekonstrukcje i kreacje zabytków były podporządkowane kształtowaniu wizji narodowej historii i gloryfikacji państwa narodowego.

Po 1989 roku nastąpiło przewartościowanie, w którym to estetyka, a nie autentyzm zabytku jest najbardziej pożądanym oczekiwaniem ze strony społeczeństwa. 
Współczesne oczekiwania sprowadzają się do tego, że zabytek ma być elementem rozwoju gospodarczego. Usprawiedliwia to ich dowolne przekształcanie, modernizowanie dla potrzeb turystyki, czy gospodarki. Dzięki odbudowie i rekonstrukcji zniszczone, czy też, nieistniejące już zabytki, na powrót stają się atrakcyjne, a przez to przywrócona zostaje siła ich obecnego oddziaływania (schemat). Nowym

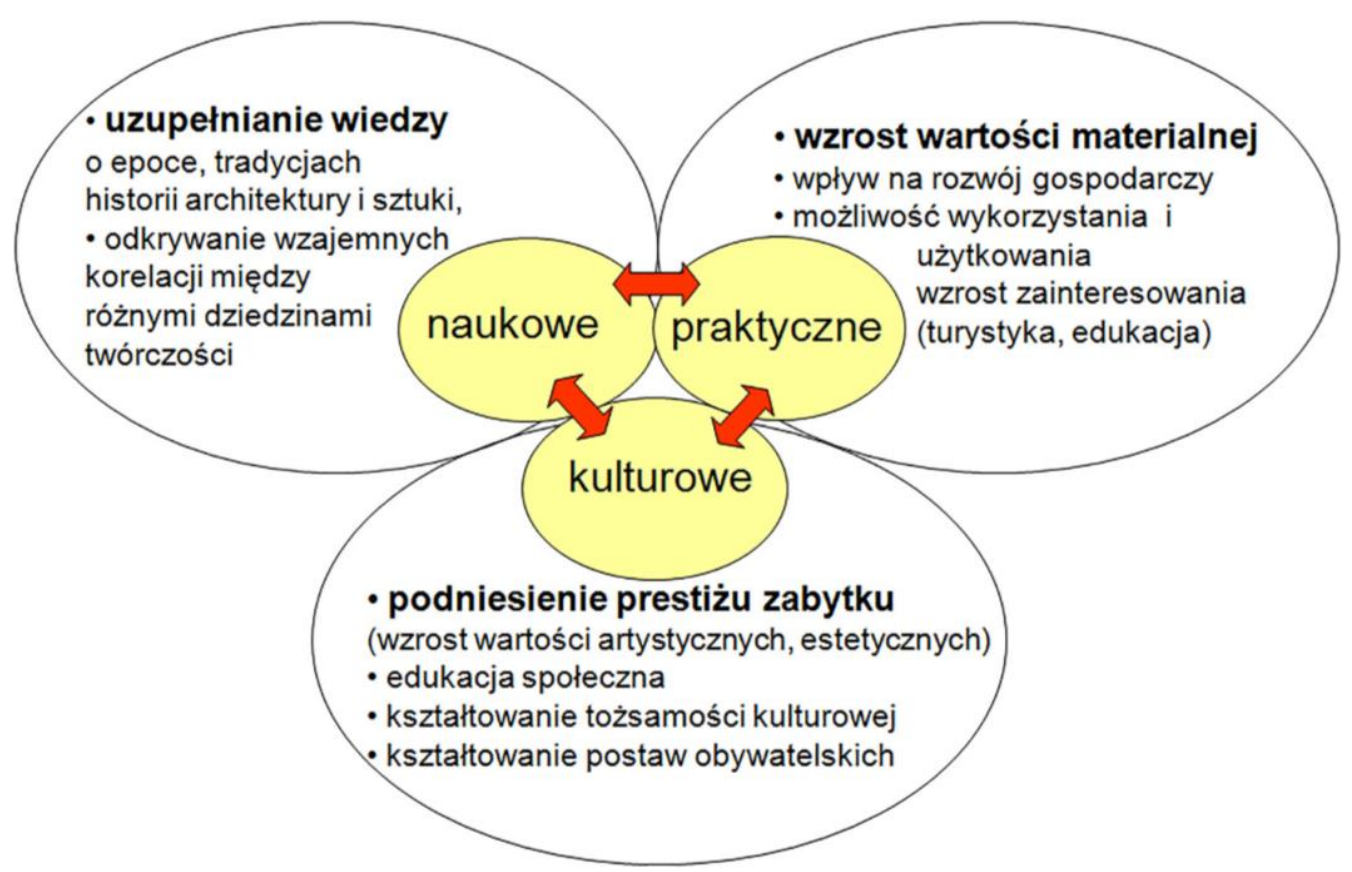

Schemat znaczenia i obszarów oddziaływania zabytków po rekonstrukcji

elementem stało się wykorzystywanie zabytków do celów komercyjnych i do potrzeb stworzenia infrastruktury turystycznej: hotele, atrakcje turystyczne. Znacznie śmielej niż wcześniej podejmowano kreacje zabytków, by poprzez ich atrakcyjny i sugestywny wygląd odpowiedzieć na potrzeby skomercjalizowanego społeczeństwa.

\section{BIBLIOGRAFIA}

Aleksejczuk, Oleg. Kijów i okolice. Bielsko-Biała: Pascal, 2006.

Ashworth, Greg. Whose History, Whose Heritage, Management Means Choice. Managing Tourism in Historic Cities. Red. K. Broński i in. Kraków: International Cultural Centre, 1992. S. 57-66.

Bakoš, Ján. “Monuments and Ideologies". Human Affairs I (1991). S. 108-119. 
Billert, Andrzej. „Uwagi o podstawach teoretycznych ochrony zabytków”. Ochrona Zabytków 3-4 (1975). S. 175-179.

Gerycz, Włodzimierz. „Problemy i tendencje ochrony zabytków sakralnych na Ukrainie”. Ochrona Zabytków 1-4 (2010). S. 7-15.

Gierlasiński, Janusz. „Odbudowa zespołu staromiejskiego w Szczecinie po II wojnie światowej - ocena zastosowanych rozwiązań". Acta Universitatis Nicolai Copernici. Zabytkoznawstwo i Konserwatorstwo. R. XLII (2011). S. 565-591.

Guerquin, Bohdan. Zamki w Polsce. Warszawa: Arkady 1984.

Kadłuczka, Andrzej. „O integracji współczesnych i historycznych struktur przestrzennych w konserwacji zabytków". Teka Komisji Urbanistyki i Architektury. T. VI (1972). S. 1-85.

Kaplica Hochberga. Wskrzeszone arcydzieło baroku. Wyd. zbiorowe. Wstęp Włodzimierz Juszczak. Wrocław: Diecezja Wrocławsko-Gdańskiego Kościoła Grekokatolickiego, 2013.

Komar, Żanna. „Budowanie historii”. Herito: dziedzictwo, kultura, wspótczesność 2 (2011). S. 160-165.

Kowalski, Tadeusz. Rekonstrukcja zabytków architektury: teoria a praktyka. Warszawa: Wydawnictwa PKZ, 1985.

Lasecki, Jarosław. „Rekonstrukcja marzeń dla regionu i potomności”. VIP Polityka Biznes Fakty. 06.04. 2010 (2010). S. 145-146. Web: 10.08,2014. <http://www.jaroslawlasecki.pl/pl/publikacje-prasowe/ rekonstrukcja-marzen-dla-regionu-i-potomnosci>

Lorentz, Stanisław. „Wokół Królewskiego Zamku”. Problemy 1 (1972). S. 2-4.

Lubocka-Hoffman, Maria. Miasta historyczne pótnocnej i zachodniej Polski. Zniszczenia i programy odbudowy. Elbląg-Bydgoszcz: Oficyna Wydawnicza Exalibur, 2004.

Łoziński, Jerzy Z. „Zabytek - pomnik historyczny, pamiątka narodowa, dzieło sztuki”. Dzieło sztuki i zabytek. Biblioteka Muzealnictwa i Ochrony Zabytków. T. XLIII seria B (1976). S. 16-17.

Majewski Jerzy S., Markiewicz Tomasz. Warszawa nie odbudowana. Warszawa: Wydawnictwo DiG, 1998.

Mangelowa, Irena. „Dziesięciolecie Lublina”. Ochrona Zabytków. R. VII. 3 (1954). S. 141-142.

Markiewicz, Tomasz. „Socrealistyczne koncepcje projektowe rozwiązania centrum Warszawy”. Historyczne place Warszawy. Red. B. Wierzbicka. Warszawa: Towarzystwo Opieki nad Zabytkami, 1995. S. 179-189.

Martyn Peter J. „Wspaniała „staronowa” stolica. Rozważania dotyczące estetyki odbudowanego oraz przebudowanego w latach 1948-55 centrum Warszawy". Falsyfikaty dzieł sztuki w zbiorach polskich. Materiały międzynarodowej konferencji naukowej zorganizowanej 21-22 maja 1999 roku przez Instytut Archeologii Uniwersytetu Warszawskiego, Oddział Warszawski Stowarzyszenia Historyków Sztuki i Zamek Królewski w Warszawie. Red. J. Miziołek. Warszawa: Argraf, 2002. S. 270-289.

Mikołajski, Olgierd. Zamek w Pieskowej Skale. Dąbrowa Górnicza: Dikappa, 2009.

Miłobędzki, Adam. „Polska szkoła konserwatorska”. Arka 49 (1994). S.131-141.

Miłobędzki, Adam. „Zabytki - polityka - kultura”. Arche 9 (1995). S. 22-24.

Miłobędzki, Adam. "Zabytki, polityka, kultura i... architektura”. Twórczość $i$ konserwatorstwo w architekturze. Materiały z sesji naukowej na posiedzeniu plenarnym Komitetu Architektury i Urbanistyki PAN 22-23 września 1995 roku w Nieborowie. Red. E. Małachowicz. Warszawa: Polska Akademia Nauk Komitet Architektury i Urbanistyki i Ośrodek Ochrony Zabytkowego Krajobrazu, 1996. S. 17-20.

Miłobędzki, Adam. „Polska szkoła konserwacji?” Kazimierz odnowiony: jego zabytki i krajobraz kulturowy. Red. A. Miłobędzki, K. Chmielewski, J. Krawczyk. Warszawa: Muzeum Pałac w Wilanowie, 2012. S. 21-26.

Murzyn-Kupisz, Monika. Dziedzictwo kulturowe a rozwój lokalny. Kraków: Uniwersytet Ekonomiczny w Krakowie, 2012. 
Podlewski, Wacław. „Zagadnienie odbudowy miast Pomorza Zachodniego”. Ochrona Zabytków 3/4 (1948). S. 110-114.

Ptaśnik, Mieczysław. „Zabytki ośrodkami turystyki”. Ochrona Zabytków 4 (1967). S. 3-5.

Romejko-Hurko, Marcin. „Piękniejsza niż kiedykolwiek... opowieść o odbudowie warszawskiej Starówki". Mówia wieki 8 (2003). S. 26-32.

Rykwert, Joseph. "Is Eurodisney a Substitute for Paris?” Times Literary Supplement, 18.09.1992; tłum. polskie: “Disneyland zamiast Paryża?” Kresy R. 3, 23 (199). S. 198-201.

Bohdan, Rymaszewski. „O zespołach staromiejskich na ziemiach zachodnich i północnych Polski po roku 1945". Ochrona dziedzictwa kulturowego zachodnich i pótnocnych ziem Polski. Red. J. Kowalczyk. Warszawa: Stowarzyszenie Konserwatorów Zabytków i Polski Komitet Narodowy ICOMOS, 1995. S. 35-52.

Rymaszewski, Bohdan. Polska ochrona zabytków: refleksje z lat 1918-2002. Warszawa: Politechnika Białostocka, 2002.

Sujecki, Janusz. „Druga śmierć miasta. Przyczyny i konsekwencje”. Historyczne place Warszawy. Red. B. Wierzbicka. Warszawa: Towarzystwo Opieki nad Zabytkami, 1995. S. 190-202.

Szmygin, Bogusław, Kształtowanie koncepcji zabytku i doktryny konserwatorskiej w Polsce w XX wieku. Lublin: Politechnika Lubelska, 2000.

Tomaszewski, Andrzej. „Konserwacja zabytków W Polsce 1945-1957: Jan Zachwatowicz”. Kwartalnik Architektury i Urbanistyki. T. XXXVIII 3-4 (1994). S. 291-295.

Zachwatowicz, Jan. "Zamek zniszczony i jego odbudowa”. Zamek Królewski w Warszawie. Wyd. zbiorowe. Wstęp A. Gieysztor. Warszawa: PWN, 1972. S. 194-196.

Zachwatowicz, Jan. „Odbudowa Zamku Królewskiego w Warszawie. Prace ArchitektonicznoKonserwatorskiej Obywatelskiego Komitetu Odbudowy Zamku Królewskiego w Warszawie". Ochrona Zabytków 1 (1973). S. 13-19.

Zachwatowicz, Jan. „Problemy restytucji Zamku Królewskiego w Warszawie”. Ochrona Zabytków 1 (1979). S. 3-17.

Zamecznik, Stanisław. „Czy park w Woli Żelazowej jest pomnikiem Chopina, Odkrycie Ameryki”. Architektura i Budownictwo. T. XIV 11-12 (1938). S. 376-382. 